\title{
How do top construction companies diversify in the international construction market?
}

\author{
Meng Ye ${ }^{1}$, Weisheng $\mathrm{Lu}^{2}$, Kunhui $\mathrm{Ye}^{3}$, and Roger Flanagan ${ }^{4}$
}

\begin{abstract}
Globalization has created an international market that allows construction companies transcend traditional national boundaries and conduct business overseas. With new opportunities being brought to contractors, competition also grows exponentially in this market. Diversification is frequently adopted by these contractors as a strategy by the contractors for either growth, or risk management, or both in this competitive environment. However, the pattern of diversification has not been well measured, mapped, and analyzed. The aim of this research is to develop a Diversify Index (DI) and examine international contractors' diversification pattern. The data is from the Top 225 International Contractors' reports ranked by ENR (Engineering News-Record) from 1995 to 2014. Distributions of the DI were explored first and then case studies were used to investigate the specific diversification strategies adopted by the top international contractors. It is discovered that a downward trend of DI with subsequent changes in rankings expresses that larger contractors increasingly adopt various diversification strategies in international competition. The results provide valuable sights on the relationship between the competitive success and their diversification strategies as well as the tendency of diversification strategies adopted by top international contractors in different regions.
\end{abstract}

Keywords: International construction; Diversification; Market competition; Competitiveness

\footnotetext{
${ }^{1}$ Ph.D. Student, Dept. of Real Estate and Construction, Faculty of Architecture, Univ. of Hong Kong, Pokfulam, Hong Kong (corresponding author). E-mail: megan828@hku.hk

${ }^{2}$ Assistant Professor, Dept. of Real Estate and Construction, Faculty of Architecture, Univ. of Hong Kong, Pokfulam, Hong Kong

${ }^{3}$ Professor, Faculty of Construction Management and Real Estate, Chongqing Univ., Chongqing 400045, China

${ }^{4}$ Professor, School of Construction Management and Engineering, Univ. of Reading, Reading RG6 6AW, U.K.
} 


\section{Introduction}

Globalization attracts lots of attention from last century on, which brings a larger market, richer resources as well as advanced technology, fast transportation, convenient communications and effective knowledge transfer. All of these have helped lower traditional barriers and encourage firms from different countries to compete and enlarge their markets. With the globalization of the world economy, today's construction business is fast becoming an internationally interdependent marketplace (Lu et al., 2014). Many large construction firms operate not only in their home country but also across country board to pursue the long-run profits, balance development, make use of resources, increase assets turnover, and most importantly, meet the market demands. Construction is a demand-oriented industry; changes of demands in one marketplace affect the profits of construction firms directly. Compared to the developed countries, less developed countries or regions, such as some Asian countries, Middle East and African area, have more demands in construction. High-speed development of economy and the progress of urbanization raise the demands of buildings and basic infrastructural services, such as electricity reticulation, roads and other means of transport, port facilities, and water supply facilities and so on. According to S.N. Subrahmanyan (Reina and Tulacz 2013, p7), senior executive vice president of India's Larsen \& Toubro Ltd., India and China will continue to be the most important construction markets, driven primarily by the irreversible forces of urbanization and infrastructure growth. Such unbalanced development of region economy drives internationalization of construction firms, making the global more internationalized than ever. According to Engineering-News Records (ENR) (2014), the ENR Top 250 International Contractors (TIC 250) had \$543.97 billion in contracting revenue in 2013 from projects outside their home countries, up 6.4\% from $\$ 511.05$ billion in 2012, and up 224.78\% from $\$ 167.5$ billion in 2004 .

With new opportunities being brought to international contractors, ever-growing competition also exists. Faced with an increasingly competitive international construction market, international contractors need to enhance their competitive advantages for surviving and sustainable development. Diversification become one of the solutions for fierce competition (Ansoff,1957). Companies diversify to compensate for technological obsolescence, to distribute risk, to utilize excess productive capacity, to reinvest earnings, to obtain top management, and so forth (Ansoff, 1957). Since then, many studies have focused on this topic, but the results vary due to different theories. On the basis of resource-based theory and economy of scope, diversification can be driven by employing the firm's intangible assets to enter into different industries (Arasti, Khaleghi, \& Noori, 2010), and it is regarded as one way to make full use of the surplus resources or core ability and decrease transaction costs (Jewell et al. 2014). Prahalad and Hamel (1994) advocate that diversified corporations should not be seen as a portfolio of discrete businesses, but as a collection of competitively important competencies that could be used in different products and markets. In this view, diversification is conducive to the growth of the corporations and related diversification is better than unrelated diversification in the case of effective use of resources. Organizational management theory provides another view into diversification. Gary (2005) presents the higher initial slack strategy, which shows a policy in which management embarks on a diversification move only when there is at least 10 percent slack in the organization. Additional organizational slack enables management to maintain the balance between shared resources and total workload demands with the extra buffer of excess resources in place before the diversification. Agency theory suggests that diversification can benefit managers and hurt shareholders (Mackey, 2006). Chandler (1969) believes that diversification would increase the complexity of organizations so that new management problems would be brought. Based on risk management theory, Berger and Ofek (1995) argue that one of the potential benefits of diversification arises from combining business with imperfectly correlated earnings streams since debt capacity can be increased by increasing interest tax shields. Chang and Thomas (1989) present their view that diversified firms would avoid specific risks. In this view, unrelated diversification performs better than related diversification.

The prolific theories provide different conjectures about diversification. Meanwhile, diversification should vary from one industry to another too. In the construction industry, the output is not specific transferable goods with short production cycle, which is so different from those in the 
manufacturing industry. Diversification in the construction industry, especially to the international markets, needs more labor, materials, machinery, and expertise to the host markets rather than just exporting commodities from the home countries. Kurien (2004) found that some construction contractors prefer to seek one particular project to enter a new market. However, how construction companies diversify in the international construction market is not entirely clear.

The primary aim of this study is to provide the empirical findings on the overall diversification pattern for international contractors. To achieve the aim, several research questions, each representing a specific objective, should be identified. It is mentioned by Reed and Luffman (1986) that firms diversify for proactive and defensive reasons. Poorly performing firms would have high motivation to search for alternate business sectors even if they are risker while highly performing firms may use diversification to improve their performance by reducing their market risks. But it is known that large firms would be rich in resources, which is beneficial for diversifying to other sectors. As international contractors are ranked based on the international revenue, one question could be raised that $Q 1$ : Would the diversification levels vary with the rankings following a specific rule? Theories related to diversification tell us different views on it, which give us a signal that diversification could not be chosen as nostrums. "The more, the better" is not the rule for any diversified firm. There may exist one proper diversification level for the international contractors. There comes the second question that Q2: What is the proper diversification level for the international contractors? Along with the rapid process of economic globalization, competition in the international market becomes fiercer. Whether diversification becomes one of the strategies accepted by the contractors or not is a big question. So, we can raise the third question, Q3: Would the diversification level be improved as time goes on?

\section{Methods}

\subsection{Sample}

Engineering News-Record (ENR) has published annual data about contractors and designers in the U.S.A and some other international markets every year since 1958. The Top 225 International Contractors (TIC225) List (has been changed to Top 250 International Contractors [TIC 250] since 2013 due to increase of the contractors) is selected as the sample given its comprehensiveness and reliability $(\mathrm{Lu}, 2014)$ in describing the presence of top contractors in the international market. International revenues, gross revenues, new contract awards, and previous year's rank of the top 225 or 250 international contractors are presented in the lists. Meanwhile, the lists also provide the percentage of international revenues in different construction business sectors for ranked firms. If the sum of the percentage is less than $100 \%$, it is explained that other kinds of businesses contribute to the international revenues. Nine construction business sectors are classified by ENR: general building (GB), manufacturing (MNF), power (PW), water supply (WS), sewerage/ solid waste (SSW), industrial process/ petroleum (IPP), hazardous waste (HW), and telecommunications (TC). Two of them, water supply and telecommunications, have been added to the lists since 2001 .

\subsection{Data}

The data used in the current study cover 20 years from 1995 to 2014. Top 225 International Contractors Lists in 20 years are collected in an excel profile. What's more, top 100 international contractors ranked in 2014 are selected to track the history, by which, one can identify how the contractors' businesses have changed through diversification over the data period. For tracking, an excel profile was developed to reorganize separate annual data sets for each of contractors. As of result, about 36 out of 100 contractors have lasted in the ENR list through the entire 20 years. The other 64 contractors have had shorter durations. The average length of appearance of the 100 firms is 14.3 years.

\subsection{Measure of diversification}

Various measures of firm diversification have been developed over the past decades. The current study uses entropy measure as shown in eq. [1] to calculate the levels of diversification, which is called diversify index (DI). This measure was first applied to the assessment of diversification by Shannon (1948) and it has several mathematical advantages: the measure is additive (it can be divided 
into additive elements that contribute to the total) and sensitive (it accounts better for low levels of diversification compared to other measures) (Choi and Russell, 2005; Jacquemin and Berry, 1979).

$$
\text { Entropy }=\mathrm{K} \sum_{i=1}^{N} p i \times \ln \frac{1}{p i} \quad \text { eq. [1] }
$$

In eq.[1], $p i$ is the revenue percentage of the firm's international revenues in the $i$ th construction business sector, $N$ is number of market sectors plus 1 (most sums of business percentage are less than $100 \%$, one more sector is assumed for the balance; therefore, $\mathrm{N}=8$ before the year 2000 , and $\mathrm{N}=10$ after the year 2000), $K$ is the coefficient of standardization, one dividing by the logarithmic value of $N$, which is the possible maximum value, so that all measures are scaled onto the interval $[0.0,1.0]$. In information theory, entropy is a measure of unpredictability of information content. The entropy of the message is its amount of uncertainty; it increases when the message is closer to random, and decreases when it is regular. So, when the firm diversity index (DI) is closer to 1, the level of diversification is higher while there is no diversification when the DI is 0 .

\section{Analysis, Results and Discussion}

\subsection{Results based on the top 225 international contractors list}

Entropy measure was used to calculate diversify index (DI) of the top 225 international contractors from 1995 to 2014 and an average DI could be calculated for each ranking. Therefore, ignoring the specific contractors, we can get a table including the averages of DI and rankings. Figure 1 shows us the relationship between the averages of DI and rankings.

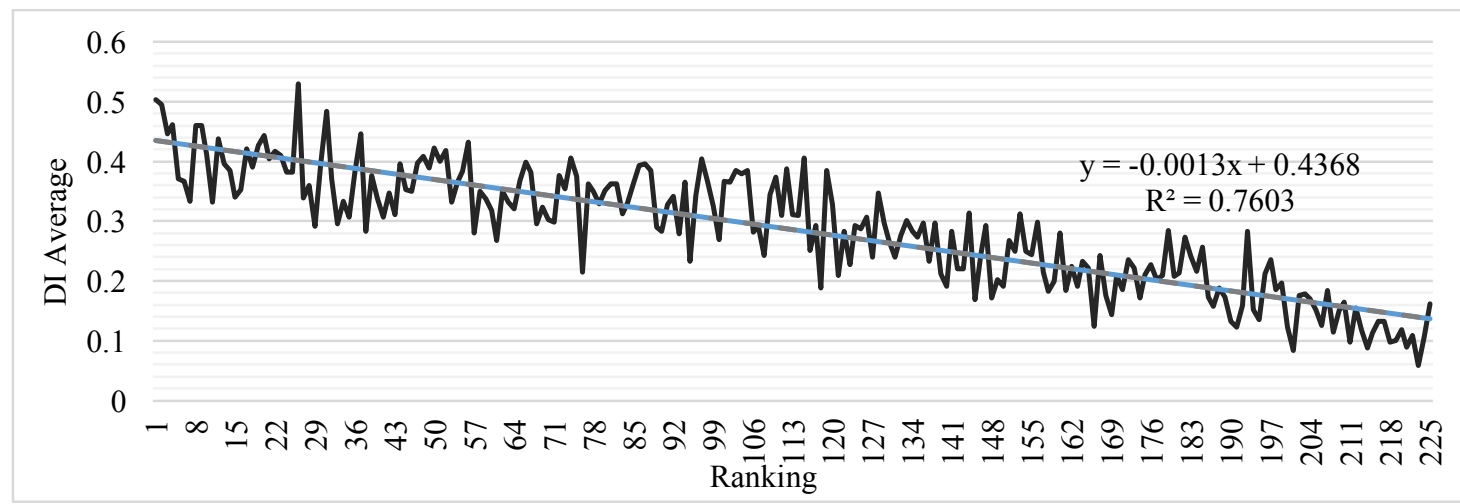

Fig. 1 The relationship between averages of diversity index (DI) and rankings

The linear trend line in Fig. 1 shows us a downward trend of DI with subsequent changes in rankings. We divide the rankings into 4 groups, which are [1-56], [57-112], [113-168], [169-225] and use the software SPSS to do the analysis of variance. P-value for test of homoscedasticity is 0.904 showing the equal variance of four groups while $p$-value for ANOVA analysis is 0 , showing the significant difference among the means of four groups. Figure 2 shows the distributions of the four groups, in which the average DIs for firms ranked 1 to 56 are between 0.3 and 0.55 , while the firms ranked 169 to 225 only have the average DIs below 0.3 . 


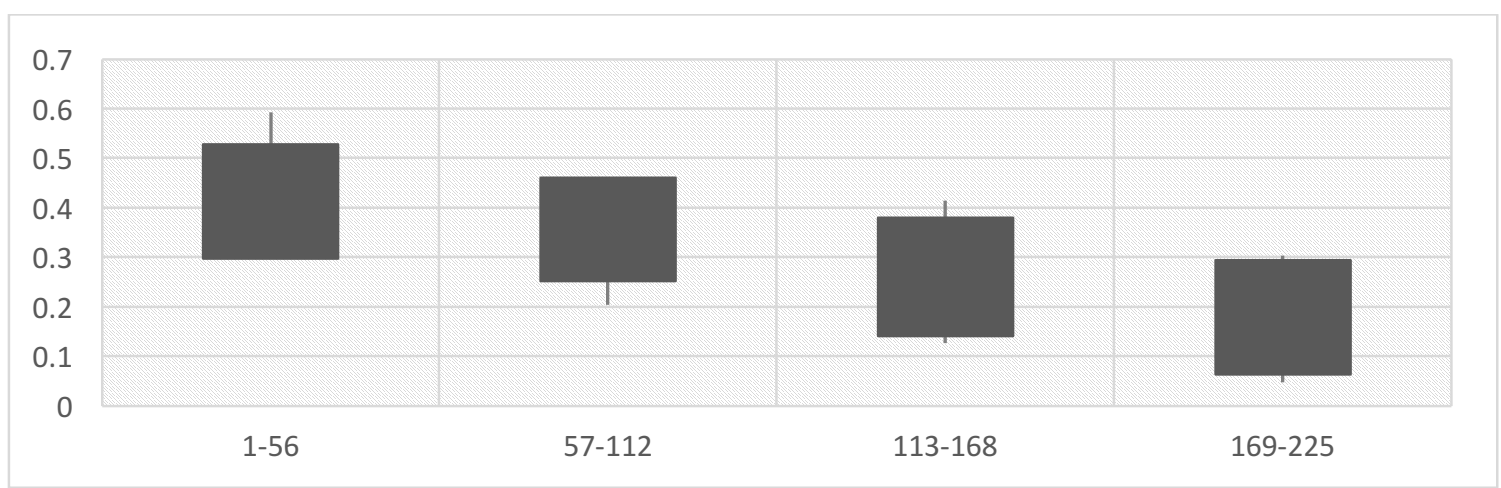

Fig. 2 The relationship between averages of diversification index (DI) and rankings in groups

According to the analysis above, the first question (Q1) could be answered. Diversification levels measured by diversify index (DI) show a downward trend with subsequent changes in rankings. Since rankings in top 225 international contractors list are based on the international revenues, which on one hand represent the size of the firms and on the other hand stand for performances, the results can approximately show that large contractors may be more diversified than smaller contractors.

\subsection{Results based on the top 100 international contractors ranked in $\mathbf{2 0 1 4}$}

As mentioned above, top 100 international contractors ranked in 2014 are selected to track the history and deal with the problems accordingly. Separate annual data sets for each of contractors from 1995 to 2014 are reorganized. The answer to Question 1 has been mentioned and results would be tested based on the top 100 international contractors. The other research questions mentioned are answered.

\section{Q1: Would the diversification levels vary with the rankings following a specific rule?}

Each contractor has its ranking and diversification index (DI) each year accordingly. Averages of DI and averages of rankings could be calculated for each contractor to do the regression analysis. The scatter diagram and linear trend line for the relationship between averages of DIs and averages of rankings are shown in Figure 3 (in which, the little blue dots represent the selected contractors). The negative correlation relationship could be reflected in the figure, which is to say, contractors with high rankings would be more likely diversified than those with lower rankings, although the results seem to be less obvious. For large contractors, they may have more resources, including intangible assets and tangible assets. On one hand, large contractors hold more mechanical equipment and labors to do work in different business sectors in the international market, and they may be less worried about the cash flows and hold the capital to diversify; on the other hand, large contractors with good performance may keep in touch with the local government in the overseas market, providing good opportunities to perform not only in one business sector.

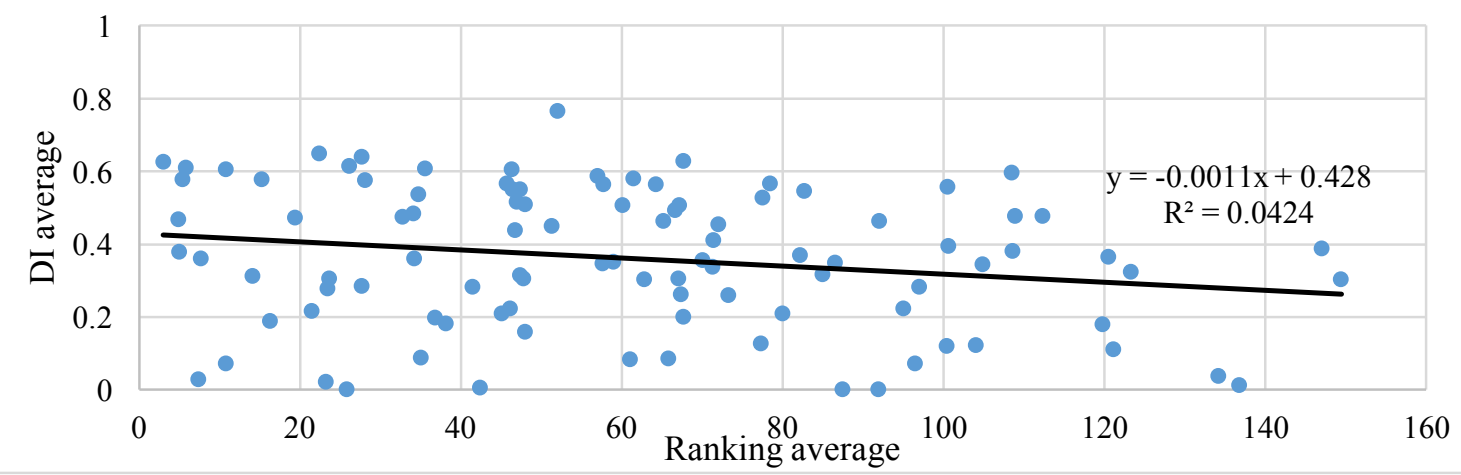

Fig. 3 The relationship between averages of diversification index (DI) and averages of rankings for the top 100 contractors ranked in 2014 


\section{Q2: What is the proper diversification level for the international contractors?}

Frequencies of contractors in different diversification levels are calculated for each year, which are shown in Figure 4. The patterns represented by the distribution of the contractors are similar over 20 years from 1995 to 2014. In Figure 5, the maximum and minimum frequencies show the range within which the largest variations have occurred during the data period. Both figures show the highest frequency in the level between 0.5 and 0.6 . The frequency of specialized contractors range from $5 \%$ to $15 \%$ with DI chose to zero. And on average, about $9 \%$ of contractors were fully specialized. Most of the contractors (above 85\%) performed their business in multiple sectors. However, there are few contractors with $\mathrm{DI}=1.0$, the maximum level of diversification, which can be attained with a uniform distribution of revenues over all sectors.

Diversification levels with DI from 0.5 to 0.6 contribute to the highest proportion almost in every single year. On average, almost $20 \%$ of the contractors has the diversification level with DI between 0.5 and 0.6 , which is the most popular diversification level. Among the top 100 international contractors ranked in 2014, about 36 of 100 contractors have lasted in the ENR list through the entire 20 years. The average length of appearance of the 100 contractors is 14.3 years, which show a well sustainable ability in the international competitive environment. The most popular diversification level seems to stand for the proper diversification level, with DI ranging from 0.5 to 0.6 .

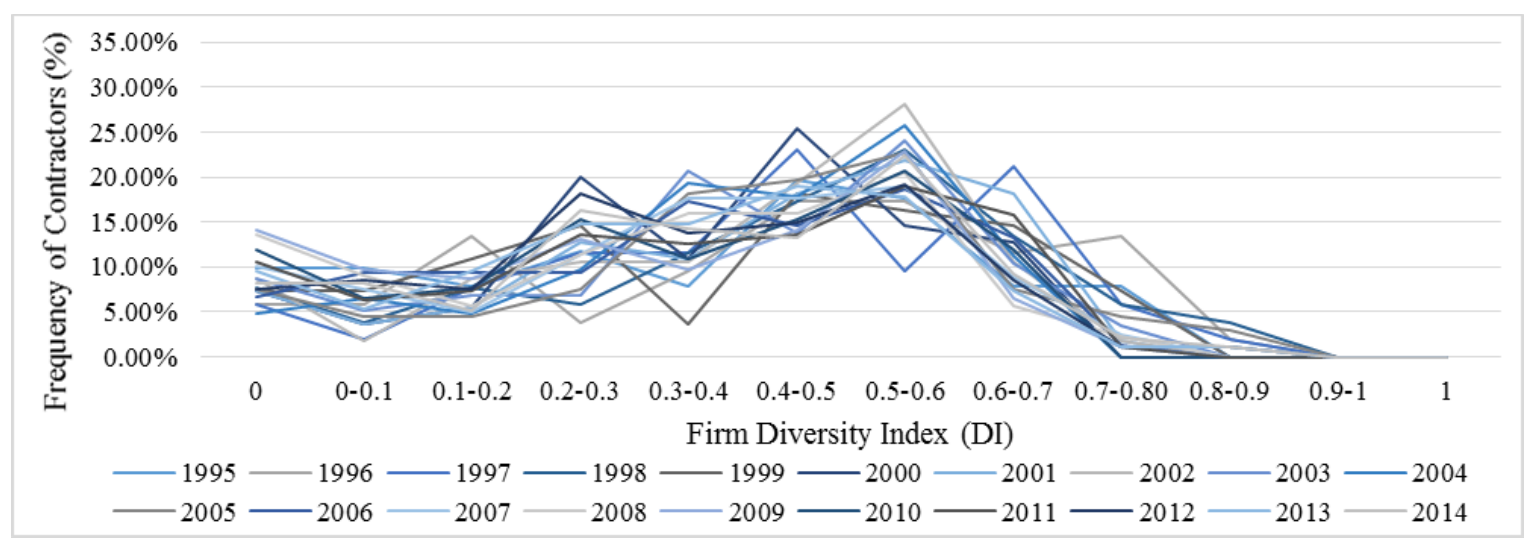

Fig. 4 Frequency of contractors in different levels of DI for each year

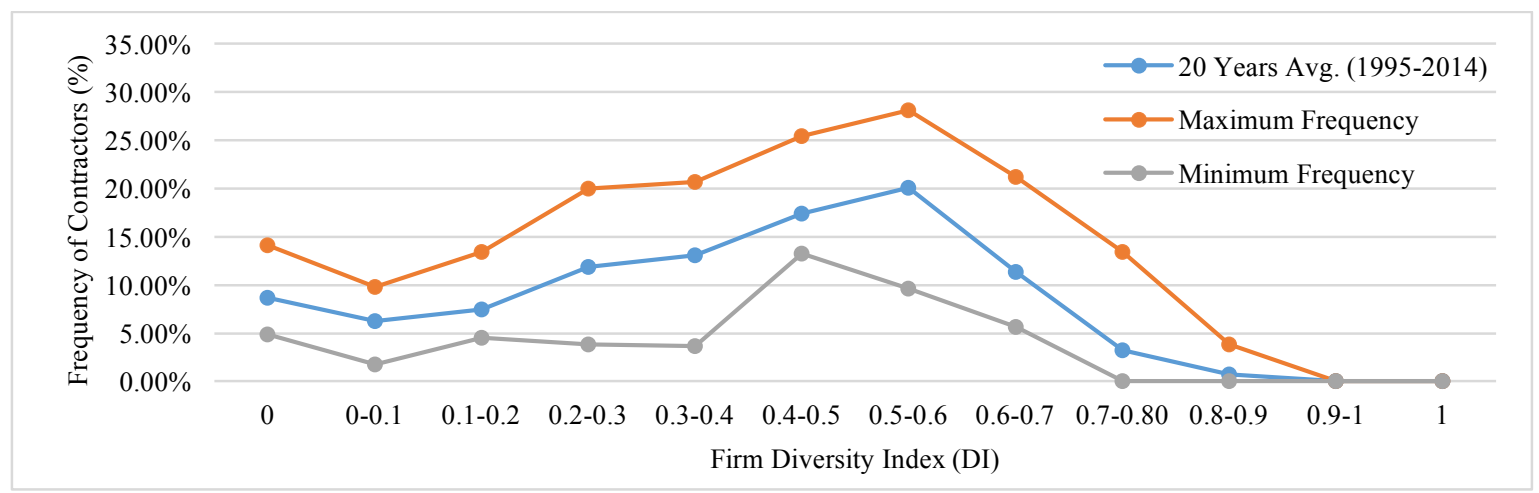

Fig. 5 Overall frequency of contractors in different levels of DI

\section{Q3: Would the diversification level be improved as time goes on?}

Figure 6 shows the total number of contractors among the top 100 international contractors ranked in 2014 on a yearly basis. Those contractors without specific data of business sectors were excluded.

Therefore, we get the contractors from 51 in 1995 to 98 in 2014. The averages of diversity index (DI) for each year could be calculated, showing a flat level, which hold the level between 0.35 and 0.45 . Although competition in the international construction market may become fiercer with the progress of globalization and internationalization, the average diversity index remains the almost the same even a little downward level. It seems that diversification is not the first choice for competing in the 
international construction market. Contractors should balance all the strategies to compete with other contractors rather than just diversifying to other business sectors.

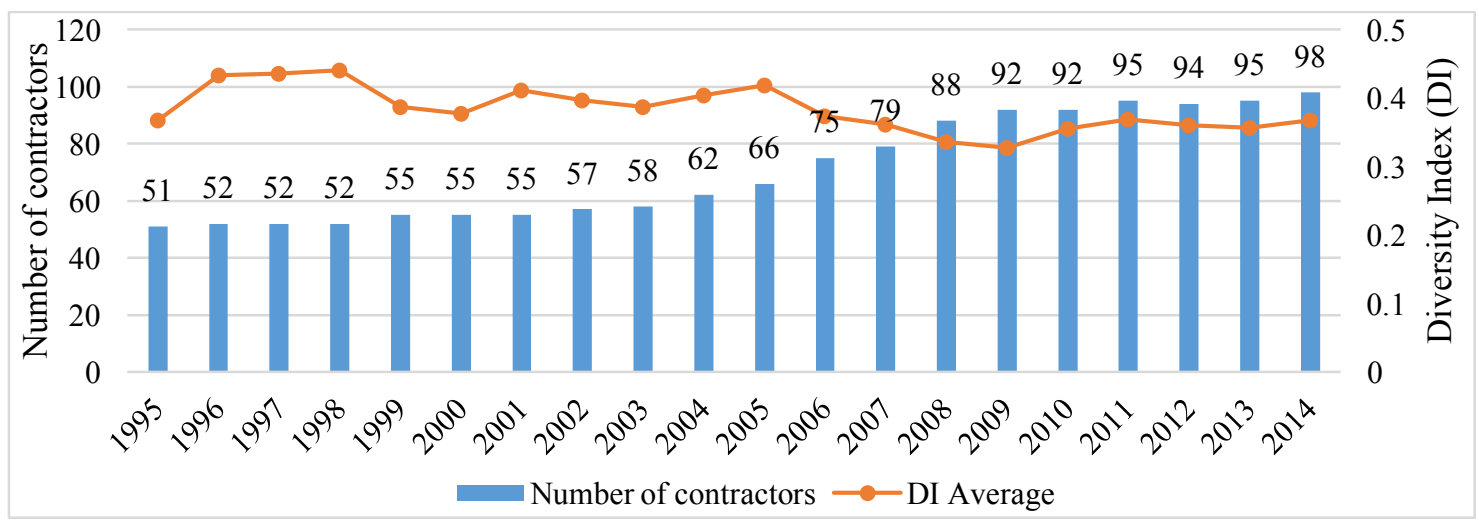

Fig. 6 Number of international contractors and averages of DI for each year

\section{Conclusions}

The study has analyzed the pattern of international contractors' market diversification using the data of Top 225 International Contractors ranked by Engineering-News Record, which cover the past 20 years from 1995 to 2014. Diversify index (DI) measured by entropy is used to reflect the diversification level of the international contractors. A downward trend of DI with subsequent changes in rankings (225 rankings in total) expresses that larger contractors increasingly adopt more diversification strategies in the international competition.

For more detailed analysis, longitudinal data of the ENR top 100 international contractors ranked in 2014 were reorganized by tracking individual contractors' annual DI and rankings over the data period. The negative correlation relationship between the average DI and average rankings shows that contractors with high rankings would be more likely diversified than those with lower rankings. This confirmed the resource-based view, which implies the competitive advantage of a firm lying primarily in the application of a bundle of valuable tangible or intangible resources at the firm's disposal. On average, almost $20 \%$ of the contractors has the most popular diversification level with DI between 0.5 and 0.6 , which indicates the proper diversification level for successfully surviving in the international competitive construction market. Moreover, the average DI in individual years show a flat level, even though the competition in the international construction market becomes fiercer.

The research provides an overall pattern of diversification, through which issues of business diversification for the international contractors can be investigated. Our findings suggest that large firms with rich resources may do well in diversification. The rule for diversification is not "the more, the better", and it may not even be the best strategy to compete. The international contractors could follow the suggested proper diversification level but decide their own diversification level accordingly.

\section{Acknowledgements}

The work is supported by the Hong Kong Research Grants Council (RGC) General Research Fund (GRF) (Project No.: HKU 749312B).

\section{References}

Ansoff, H. I. (1957). Strategies for diversification. Harvard business review, 35(5), 113-124.

Arasti, M. R., Khaleghi, M., and Noori, J. (2010). The linkage of technology strategy and overall strategy of multi business diversified groups: Literature review and theoritical framework (pp. $1-12)$. 
Berger, P. G.,and Ofek, E. (1995). Diversifications effect on firm value. Journal of Financial Economics, 37(1), 39-65. doi: 10.1016/0304-405x(94)00798-6.

Jewell, C., Flanagan, R., and Lu, W.S. (2014). The dilemma of scope and scale for construction professional service firms. Construction Management and Economics, 32 (5), 473-486.

Chandler, A. D. (1969). Strategy and structure: Chapters in the history of theindustrial enterprise: Massachusetts Institute of Technologie.

Chang, Y., and Thomas, H. (1989). The impact of diversification strategy on risk - return performance. Strategic management journal, 10(3), 271-284.

Choi, J., and Russell, J. S. (2005). Long- Term Entropy and Profitability Change of United States Public Construction Firms. J. Manage. Eng., 21(1), 17-26. doi: 10.1061/(ASCE)0742597X(2005)21:1(17)

Gary, M. S. (2005). Implementation strategy and performance outcomes in related diversification. Strategic management journal, 26(7), 643-664. doi: 10.1002/smj.468

Jacquemin, A. P., \& Berry, C. H. (1979). Entropy Measure of Diversification and Corporate Growth. The Journal of Industrial Economics, 27(4), 359-369. doi: 10.2307/2097958

Kurien, S.A. (2004). Business development strategies used by general contracting construction companies in Texas for maket diversification. M.S. thesis, Department of Cosntruction Science, Texas A \& M University, College Station, Tex.

Lu, W. (2014). Reliability of Engineering News- Record international construction data. Construction Management and Economics, 1-15. doi: 10.1080/01446193.2014.919403

Mackey, T. B. (2006). Essays on corporate diversification and firm value. Thesis (Ph.D.)--The Ohio State University, 2006.

Reed, R., and Luffman, G. A. (1986). Diversification: The growing confusion. Strategic management journal, 7(1), 29-35.

Reina, P., and Tulacz, G. J. (2013). The top 250 international contractors. Engineering News Record, 271(8), 1-19.

Shannon, C. E. (1948). A mathematical theory of communication. The Bell System Technical Journal, 27(3). 